\title{
Brexit and the UK Automotive Industry ${ }^{1}$
}

\author{
David Bailey ${ }^{2}$ and Lisa De Propris
}

Aston Business School and Birmingham Business School

\begin{abstract}
:
The UK's automotive industry has been one of the 'star performers' of the UK economy in recent years - unlike most other manufacturing sectors. Output has increased by over $60 \%$ since 2010 and there has been over £8bn worth of investment in the industry in the last five years. The industry supports some 800,000 jobs in the UK. The industry is seen as having benefitted from EU membership. So what might Brexit mean for the UK automotive sector, and its workers? This paper considers short run impacts, before turning to the impact of uncertainty on foreign direct investment inflows and then the nature of a possible trading relationship. Some brief reflections on policy implications round off the paper.
\end{abstract}

\section{Introduction}

The upturn in the UK automotive industry in recent years has seen output increasing by over $60 \%$ since 2010 , with over £8bn worth of investment in the industry in the last five years (SMMT, 2016). The industry supports some 800,000 jobs in total in the UK. This upturn has benefitted regions, such as the West Midlands which have struggled with deindustrialisation, plant closures and the legacy of the global financial crisis (Bailey and Berkeley, 2014; Bailey et al 2015; Bailey and de Ruyter, 2015). There are many reasons for this recent automotive industry success - the skills base, cooperative working between unions and management, links with universities, a supportive industrial policy and so on. But it should also be noted that a key factor for the success has also been access to the EU Single Market. Indeed, the industry is seen as having benefitted from EU membership, and not only in

\footnotetext{
${ }^{1}$ Acknowledgement: The writing of this paper has been supported by the EU Horizon 2020 project MAKERS - Smart Manufacturing for EU Growth and Prosperity, a project funded by the Horizon 2020 Research and Innovation Staff Exchange Programme, under the Marie Sklodowska-Curie Actions, grant agreement number 691192. It builds on and updates Bailey and De Propris (2017).

${ }_{2}^{2}$ Corresponding author. Contact: d.bailey@aston.ac.uk
} 
accessing the single market, but also through the EU cutting trade deals with the rest of the world, in the UK influencing EU regulations, and in accessing skilled workers and European research funding and networks (KPMG, 2014). So what might Britain's departure for the EU mean for the UK automotive sector (hereafter 'UK auto')?

This paper considers short run impacts, before turning to the effect of uncertainty on foreign direct investment (FDI) inflows, firm specific impacts, the nature of a possible trading relationship, and some brief reflections on policy implications.

\section{Short-run Market and Production Impacts}

A starting point in understanding the impact of the Brexit vote on the UK auto industry is to consider its impact on the wider UK economy, both in terms of economic growth and the value of sterling. For example, a possible slowdown in economic growth is likely to impact on car sales in the UK, so at best car sales are likely to grow more slowly than otherwise and at worst may fall. For example, PA Consulting forecast a possible fall in UK car sales in the 5\%-10\% range (PA Consulting, 2016) post Brexit referendum, while the consultancy firm LMC revised down its base forecast for the UK's light vehicle market by $15 \%$ to $2.55 \mathrm{~m}$ units for 2018 (versus 3m units in 2015) - a reduction in forecast market volume of over 400,000 units for 2018 (LMC, 2016). ${ }^{3}$ However, this negative outlook for the auto market was offset to some extent by the Bank of England's loosening of monetary policy immediately after the referendum (including cuts in interest rates and more quantitative easing), which helped to reduce financing rates on new cars. The Bank is now signalling that rates may rise, and is also concerned over the financing of new cars, with a suggestion that it may impose tougher lending criteria (Bailey and Chapman, 2017).

With regards to the currency, the value of sterling fell significantly in the aftermath of the Brexit vote (notwithstanding the recovery in Sterling's value in late 2017). For UK based auto assemblers, this depreciation should boost exports. In response to this,

\footnotetext{
${ }^{3}$ In August 2016 GM was the first European producer to announce that it was cutting production in Europe in anticipation of a slowdown of UK car sales. Ford also cut third quarter European output by over 80,000 units in the wake of the Brexit decision.
} 
firms have a choice between increasing output and increasing prices to raise margins. ${ }^{4}$ Nevertheless, this should help boost UK auto output in the short term to over $1.8 \mathrm{~m}$ units. ${ }^{5}$ So the immediate likely impact on UK auto would seem to be 'output up but domestic sales down'.

At the same time, however, imported cars and components will become more expensive for the consumer and industry alike. On average, only around $40 \%$ of the components that comprise a UK assembled car are sourced locally, as against $60 \%$ in Germany (SMMT, 2016), given the nature of fragmented supply chains in UK automotive (Bailey and De Propris, 2014). By late 2016 the exchange rate depreciation was already feeding through into inflation, especially in relation to imported components and factory input prices. ${ }^{6}$ Such forces will impact on different firms in different ways. Jaguar Land Rover, for example, source a higher proportion of components in the UK and also have higher margins to play with than, say, General Motors through its Vauxhall brand. Both firms have worked hard in recent years to raise their levels of UK sourcing. That could become an imperative if sterling settles down at a lower exchange rate and imported components become too costly. Those auto brands that do not assemble in the UK and only import cars have been affected negatively by the fall in sterling over the last year as their cars have become more expensive here (or their margins are squeezed). So in terms of the auto market in the UK, the 'bottom line' is that cars (whether imported or made in the UK) are likely to become more expensive; this can be seen in prices edging over since late 2016 notwithstanding recent discount and 'scrappage' schemes as the UK auto market has softened. ${ }^{7}$ Furthermore, as noted, a slowdown in economic growth is also likely, which will impact on car sales.

\section{Uncertainty and FDI}

\footnotetext{
${ }^{4}$ ONS data seems to suggest the latter more broadly (The Guardian, 15/09/2017).

${ }^{5}$ As noted, a weak UK currency (sterling) might offer an export advantage, if it persists over time, but in low-margin manufacturing such as mass market auto, currency fluctuations may be seen as a negative strategic factor for investors (LMC, 2016b).

${ }^{6}$ The Office for National Statistics stated in August 2016 that input prices rose 4.3\% in July 2016, the first annual increase since September 2013 (Financial Times, 16/08/2016).

7 Dhingra et al (2016) suggest that UK car prices could rise by $2.5 \%$ after Brexit.
} 
There are a number of ways in which Brexit could impact on FDI flows to the UK whether from the EU or beyond (Dhingra et al, 2016; Driffield and Karoglou, 2016; Bailey et al, 2017). Firstly, as in other manufacturing sectors, auto production is fragmented along global value chains (GVCs) of multi-tier suppliers that cross borders and continents. Such GVCs are coordinated from strategic locations where the original equipment manufacturers (OEMs) are located and fan out seeking to maximize strategic advantages. Coordinating such supply chains may become more costly with Brexit. Components going into modules that are put together by systems integrators for delivery to final auto assemblers may be subject to different regulations, for example, or be subject to import duties when the UK has left the EU. Secondly, FDI-flows into the UK have been used as a platform to access the EU Single Market, with multinationals benefitting from the elimination of tariff and nontariff barriers. This may change if the terms of trade agreements with the EU are redrawn. Indeed, ongoing uncertainty over the nature of future trading relations between the UK and the EU is likely to affect inward investment in the industry in the UK. Foreign investment has been key to the renewal of the industry, with some £8bn invested in the sector over the last five years (SMMT, 2016) and £1.66bn invested in 2016 (Financial Times, 2017). That fell to some $£ 322 \mathrm{~m}$ in the first half of 2017 (ibid).

As Bailey et al (2017) note, the biggest single deterrent to foreign investment is uncertainty. The more uncertainty that firms attach to their 'net present value calculations', the less likely they are to invest. They note that the single event that caused the greatest decline in inward investment in recent history was Britain leaving the Exchange Rate Mechanism, not because it necessarily implied any particular weakness about the UK economy, but because of the uncertainty that surrounded it. In contrast, they note that the single event that has had the greatest positive impact on inward investment in the UK in recent history was the creation of the single market. This was because it became easier for firms to conduct business within their organization across national borders. For example, automotive and engine assemblers like GM, BMW and Ford all import sizeable inflows of components to the UK from their other EU operations and from the broader value chain.

The key point here is that trade is no longer bilateral between countries; rather trade is characterized by fine grained cross-border GVCs where the end product incorporates inputs from multiple origins. Indeed, industrial production today occurs 
through the veins of global production networks (Coe and Yeung, 2015) that span borders and are headed by multinationals (some of which are starting to originate from emerging economies such as China; Matthews, 2006). The GVC model suggests that not all stages of production contribute with the same value added to the final product (Gereffi et al 2006). As KPMG (2014) illustrate, a typical driveline system produced by GKN, the British-based supplier of automotive driveline technologies and systems, incorporates specialist forged parts from (left to right in the figure) Spain, France, Germany and Italy which are then assembled at GKN Driveline's UK factory and supplied to automotive assemblers in the UK and EU. This is illustrated in Figure 1 below. $^{8}$ The components, assembled drivelines and the then final assembled car could cross the English Channel several times.

\section{Case study}

\section{GKN Driveline - Illustration of an integrated supply chain} A typical driveline system produced by GKN incorporates specialist parts largely from the rest of the EU.
GKN sources specialist forged parts from Spain, Italy, France and Germany which are then assembled at GKN Driveline's
factory in the UK and supplied to UK and EU OEMs.

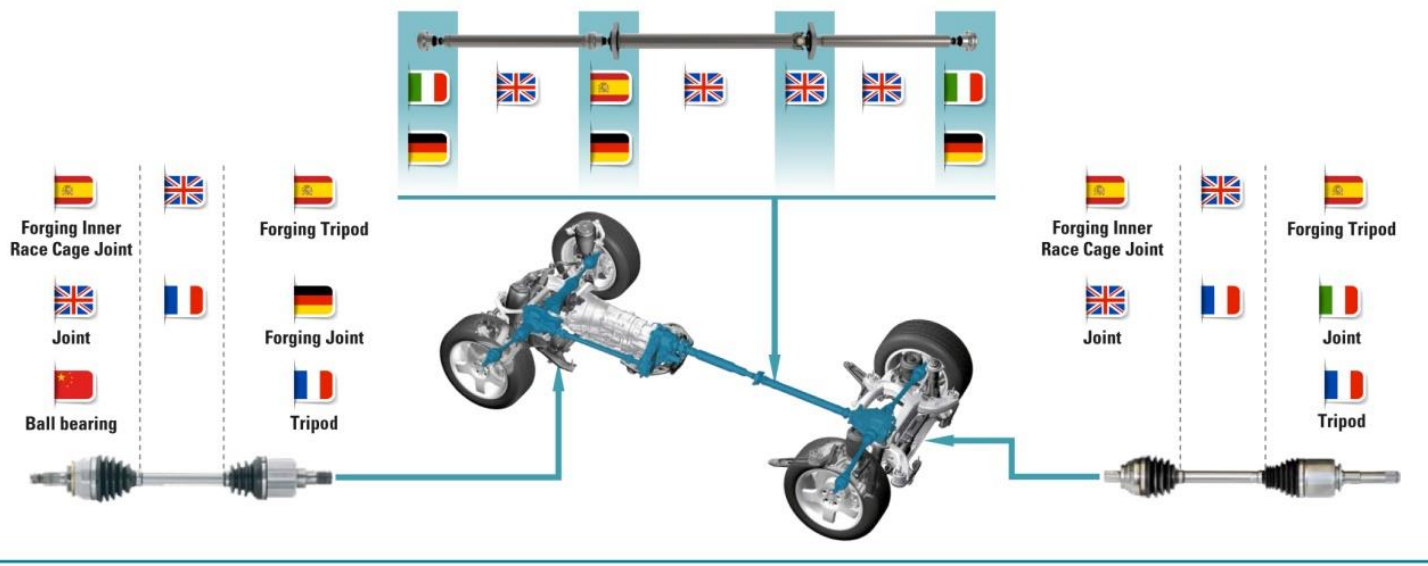

Figure 1: GKN Drivelines: illustration of an integrated supply chain.

As noted above, these value chains need to be 'frictionless' in terms of non-tariff barriers (think of regulations and standards) as well as tariffs. As KPMG (2016: 13) noted before the vote:

"Original equipment manufacturers such as aircraft and automotive manufacturers could perhaps favour the simplicity and flexibility of an EU-supply base rather than dealing with the potential complexities of a company based outside the union. In the long term, more EU-based alternatives would emerge. As buyers churned their

\footnotetext{
${ }^{8}$ Reproduced with permission of KPMG.
} 
suppliers, UK firms might become more marginalised. The integration of supply chains is a double edged sword - our manufacturers are not indispensable".

Anything which puts these value chain relationships at risk, whether currency risk or higher transactions costs from having to deal with EU and UK regulations separately, reduces the likelihood of further investment. As Driffield and Karoglou (2016) note, if one looks at past events in terms of magnitude, Brexit may have a short term negative shock on inward investment. They suggest that it would then take about 4 years for the UK to get back to a new lower long-term trend of inward investment.

The trade issue is also critical as over $80 \%$ of cars assembled in the UK are exported, and over $50 \%$ of these exports go to Europe (SMMT, 2016). Maintaining access to the Single Market is therefore critical. The uncertainty on trade needs to be 'nailed down' as soon and as clearly as possible so that investors can retain confidence that they can assemble in the UK, accessing components through European value chains, and then export the end product to Europe without tariff or non-tariff barriers. A transitional deal is hence important not only to avoid a 'cliff edge' Brexit but also to underpin short term investment in the auto industry.

\section{What trading relationship?}

As noted, the UK has yet to say what trading relationship it wants with the EU. Brexiteers didn't actually spell out what they wanted and may not actually agree, and it's not clear how the EU will in turn respond. At the time of writing (October 2017) it is not clear how this will play out. It should be noted that if the UK was to fall back on World Trade Organisation rules in the absence of a trade deal with the EU then tariffs on cars could be as high as $10 \%$, and on components as high as $4 \%$. The industry body the Society of Motor Manufacturers and Traders (SMMT) has stated that if trade tariffs are imposed it is likely to mean $£ 2.7 \mathrm{bn}$ of levies on cars being imported into Britain and £1.8bn on those being exported (SMMT, 2016b). A tariff of $10 \%$ on completed cars would represent a considerable burden for the mass market (i.e. non premium) industry and would represent far more than the total of wages and profits in the industry (Holmes, 2016).

On trading arrangements post-Brexit, during the referendum campaign, some suggested that Norway and Switzerland are examples that could be followed, as 
they are outside of the EU and enjoy forms of free trade with the EU. Switzerland's position is somewhat complicated and based on a number of bilateral agreements. Some sectors of its economy are not covered (most financial services, for example). It's a kind of a-la-carte 'Swiss Cheese' approach. Like Switzerland, Norway pays into the EU budget and gets access to the single market (on a comprehensive basis in its case), but must follow EU rules and has no input into devising EU regulations. In both cases, they are free to negotiate trade deals independently of the EU. So, could the UK 'do a Norway' and stay in the single market at least as part of a transitional deal? That would minimize the economic damage of leaving the EU, but will be tricky given that the Leave campaign had immigration as a core issue. Complete freedom of movement for people in the single market is likely to remain a sticking point for the UK, as might be paying into the EU budget as part of a transitional arrangement.

Of course, some auto firms based in mainland Europe will want to continue to trade with the UK (the UK is BMW's second largest market in Europe for example) and are already taking a 'hit' on exports to the UK with the depreciation of sterling. There will be some desire to get a deal of sorts done. ${ }^{9}$ Yet completely free trade on all goods and services (as now) but without paying into the EU budget or agreeing to the free movement of people seems a non-starter. A deal will have to be done, but the compromise will take some time to sort out, and that uncertainty is itself a major risk in terms of inward foreign investment in the auto industry. So there is uncertainty, and industry is uncertain as to how long it will go on. An interim or transitional deal on trade and access to skills is seen as critical by the industry (SMMT, 2017).

As Holmes (2016) notes, there are practical difficulties to be overcome with sectoral deals for industries like auto. A full Free Trade Agreement (FTA) would make exported cars free of tariffs into the EU, but to benefit from this they need to meet the EU's FTA Rules of Origin. Currently, these require $60 \%$ of a car's value added to be 'local' to benefit from the FTA (or with parts and components from the EU under a so-called 'cumulation' agreement). So to eliminate border bureaucracy there would need to be an FTA arrangement and a Mutual Recognition agreement for conformity

\footnotetext{
${ }^{9}$ Note, though, the attitude of the German Automotive Industry Association. A spokesperson stated: "If you want full access to the market, that comes necessarily with the free movement of people. That's the bitter pill the Brexiteers have to accept" (AutoExpress, 28/06/2016).
} 
assessment. ${ }^{10}$ However, to ensure automatic mutual recognition of the UK's conformity assessment, EEA states have to accept supranational enforcement. This could violate a UK 'red line' in Brexit talks. One possibility would be to sign a special FTA agreement in which both sides agreed that in industries where the UK keeps the same external tariffs as the EU's common external tariff then rules of origin would not be checked. As Holmes (2016) notes, such a deal is imaginable in cars because both sides have an interest in maintaining value chains in the sector.

\section{Firm Specific impacts}

The switching of assembly location mid-cycle for models currently made in the UK is not likely given high 'double running' costs in tooling and logistics. What is much more likely, though, is a shift of assembly at the point of model replacement or when new models are launched (LMC, 2016b). Companies assessing their assembly location will consider a range of issues in making such decisions, including:

- The relative cost differences between UK and EU locations;

- The dependency of sales of the particular model on the European versus the UK market;

- The relative importance of "Made in Britain" to the brand (which is more relevant for premium and luxury brands);

- The volume of imported components;

- The location options in the EU (linked to how much -capacity still exists in the European auto industry); and

- The profitability of UK operations, and how reduced free-trade conditions with the EU would affect this.

\footnotetext{
10 There are a number of issues here. Common standards are necessary but not sufficient to eliminate technical barriers to trade. National and EU law lays down 'Conformity of Assessment' rules for the tests that car makers have to pass to prove their cars' compliance with standards (Holmes, 2016). Before this, the car market in Europe was segmented as each country had its own testing regime; countries did not recognise others' 'Type Approval certificates' (ibid). Today, the EU and the wider EEA (EU plus Norway, Iceland and Liechtenstein) have a mutual recognition system around testing and certification. As Homes (2016) notes, cars assembled in Sweden by Volvo (which is Chinese owned) do not need papers to show that they satisfy Norwegian safety rules, but they do need to show that they do not contain more than $40 \%$ Chinese components. Within the EEA all states have the same mandatory standards and EU-accredited system to enforce conformity of assessment.
} 
Uncertainty in particular over the possibility of tariffs places a question mark over the future of a number of UK plants and jobs. Furthermore, as supply chain investment moves with assemblers' volumes, there could be a broader knock-on effect. It should also be noted that automotive technology is changing rapidly with developments in electric cars, connected cars and autonomous (driver-less) cars. As LMC (2016) note, a lack of FDI in such new technologies could have "a long term impact on the competitiveness of the UK industry."

A major risk facing UK auto is that investment decisions for the launch of new vehicle models are made several years in advance, often with plants engaged in 'locational tournaments' to win contracts to build the new models. For many companies those decisions are set to be made in the middle of Article 50 negotiations. As LMC (2016b) notes, "new investment initiatives in the UK, such as expansion of current manufacturing activity, or new capacity for manufacturers that have alternatives to the UK appear unlikely until current uncertainty diminishes. Such uncertainty has the potential to last for several years".

\begin{tabular}{|l|l|l|l|l|l|l|l|l|}
\hline & 2017 & 2018 & 2019 & 2020 & 2021 & 2022 & 2023 & 2024 \\
\hline Honda & Civic & & & & & & Civic & \\
\hline Vauxhall & & & & & Astra & & MPV & \\
\hline Mini & & Countryman & & & & Clubman & Mini & \\
\hline Toyota & & $\begin{array}{l}\text { Auris } \\
\text { Avensis }\end{array}$ & & & Quashaai \\
Nissan & $\begin{array}{l}\text { Leaf } \\
\text { Juke }\end{array}$ & Note & $\begin{array}{l}\text { Infinity } \\
\text { Q30 }\end{array}$ & & & \\
\hline Jaguar & XJ & & & F-Type & XF /XE & $\begin{array}{l}\text { F- } \\
\text { Pace }\end{array}$ & XJ / XJR \\
\hline $\begin{array}{l}\text { Land } \\
\text { Rover }\end{array}$ & & Evoque & $\begin{array}{l}\text { New } \\
\text { Defender }\end{array}$ & $\begin{array}{l}\text { Range } \\
\text { Rover } \\
\text { Sport }\end{array}$ & & $\begin{array}{l}\text { Discovery } \\
\text { Sport }\end{array}$ & & $\begin{array}{l}\text { Evoque } \\
\text { Discovery }\end{array}$ \\
\hline
\end{tabular}

Key: italics: choices over factory likely made. Bold: choices over factory yet to be made

Table 1: Factory Location Choices (adapted from PA Consulting, 2016)

As table 1 shows, investment decisions are already likely to have been made for the production of new car models in 2017-2019, including the Nissan Leaf and Juke and the Toyota Auris. However, the investment decisions for most cars which will be manufactured after 2019 are yet to be made. These include future generations of the Vauxhall Astra, Honda Civic, Toyota Auris and Range Rover Sport. 
Those investment decisions will be made in what looks to be at least a two-year window of uncertainty. Car makers will ask: Will the UK have access to the Single Market? Is investing in UK production worth the risk? This risk is greater for 'mass market' producers who operate on low margins, low capacity, are reliant on exports and have new models at the planning stage. This is why PA Consulting (2016) sees Toyota and Honda plants as at the most risk - although LMC (2016b) sees the Vauxhall Ellesmere Port plant as most at risk (for example given the high degree of imported components). The takeover of GM Europe (including Vauxhall) by PSA Group adds to this uncertainty given that the latter will be looking for significant cost savings (Bailey, 2017).

A potential withdrawal of investment was raised by Nissan and by Ford in relation to engine assembly, and the Japanese government has raised concerns over the Brexit process and how this could impact on Japanese investment in the UK (Government of Japan, 2016). The Japanese government's memorandum has emphasised the need for the UK to retain maximum contact with the Single Market and maintain free movement of workers between the UK and EU. The Japanese Ambassador to the UK has warned that Japanese firms could disinvest from the UK if Brexit meant that they could not make sufficient profits (The Guardian, 2016). Most recently Toyota has stated that while it wishes to build the next generation Auris model at its Burnaston plant in the UK, such a decision depends on a transitional deal being put in place (Just Auto, 2017).

Nissan itself initially stated that it would defer decisions on where to build new generations of models currently assembled at its Sunderland plant, with the RenaultNissan CEO Carlos Ghosn stating "important investment decisions will not be made in the dark" (Financial Times, 29/09/16). It was thought that the firm was going to make the Qashqai and XTrail model decisions in early 2017 but appeared to have pulled forward the decisions to maximise leverage on the UK government in the wake of the Brexit vote and uncertainty over the future of the UK's trading relationship with the EU. The British government knew that it couldn't afford to lose the Qashqai investment and Nissan effectively held a big gun to its head. A deal was done and Nissan announced that it would build the next generation Qashqai and 
XTrail at Sunderland after having received 'assurances' from the UK government (we return to industrial policy below). Nissan has since said that this decision will be reviewed once the terms of Brexit become clearer.

The government has remained tight-lipped on what support was offered, even declining to answer requests from the Office for Budget Responsibility as to whether any contingent liabilities arise from the deal (The Guardian, 23/11/16). The Qashqai decision was clearly good news for the industry and reflected the underlying competitiveness of the Sunderland plant. Yet the bigger battles in securing investment in UK auto lie ahead - at Honda, Toyota and Vauxhall - all of which are more at risk of switching production from the UK to Europe if uncertainty over the UK's trading relationship with Europe is not clarified sooner rather than later.

While firms like Nissan will certainly face challenges if the UK does not have the access to the Single Market, manufacturers may also try to use uncertainty as an excuse to cut capacity in the UK as part of wider efforts to reduce over-capacity in Europe (especially so given how easy it is to lay off workers in the UK compared with other EU countries). Ford has already scaled back investment at its Bridgend engine plant, although it has denied this is linked with Brexit.

It should be noted that the UK auto industry's success rests in large part on its productivity. The UK auto industry boasts plant utilisation running at over $70 \%$, with several plants running 24/7 operations (KPMG, 2014). This compares favourably to European nations such as Italy, where utilisation runs at just over $50 \%$. For example, Nissan's Sunderland car plant was the UK's most productive in 2015, building onein-three of all new vehicles. The risk is that some firms will try to take advantage of spare capacity on the continent, shifting production from the UK at the time of new model launches, especially if uncertainty can be used to justify it. While some commentators such as LMC (2106b) note that while a 'Hard Brexit' (here meaning exiting the Single Market) may not represent a severe blow to UK auto, some volume (and by implication jobs in assembly and the supply chain) is likely to be lost over the medium to long term. LMC (2016b) note that "new investment initiatives in the UK, such as expansion of current manufacturing activity, or new capacity for 
manufacturers that have alternatives to the UK appear unlikely until current uncertainty diminishes. Such uncertainty has the potential to last for several years". ${ }^{11}$

\section{Other impacts}

Even with a trade deal, there is one area where UK auto will definitely lose out, and that is via the inability to influence regulation in the industry. Regulation is not going away and if anything will become more important as the industry moves towards connected and autonomous cars. The UK will have no influence on shaping those regulations in Europe when it leaves. Jaguar Land Rover, for example, will have to look to the Slovakian government to represent it at the European level when the UK does exit (given that it is investing in an assembly plant in Slovakia).

A second possible impact centres on the availability of skilled workers. The auto industry currently has some 5,000 vacancies and needs to be able to hire skilled workers from Europe (SMMT, 2016). Again, this needs to be sorted out as quickly as possible. The extent to which automotive firms in the UK are affected by controls on immigration will, of course, depend on the nature of any new rules. One option could be to extend current rules for non-EU/EEA nationals to all non-UK nationals (House of Commons Library, 2016). This would effectively restrict economic migration to highly skilled migrants, reducing the inflow of migrant workers doing low-skilled jobs. However, as noted by the Social Market Foundation (2016), only $12 \%$ of current EEA employees working in the UK as a whole would meet visa requirements that currently apply to non-EEA workers. This might lead to labour shortages in those sectors which employ a higher share of EU migrants in their workforce, including manufacturing (at 10\%) (House of Commons Library, 2016). A more restrictive immigration system might also increase burdens on automotive firms if they have to spend time and resources on obtaining visas and complying with more detailed immigration regulations.

\footnotetext{
${ }^{11}$ Dhingra et al (2016), drawing on Head and Mayer (2015) suggest that if the UK were not able to maintain tariff-free access to the EU, UK auto output could fall by $12 \%$ if the wake of Brexit, with production shifted to elsewhere in the EU and possibly other locations.
} 
A third impact relates to university and industry access to European research funding, such as through Horizon 2020 (H2020). This is relevant as tens of millions of pounds of $\mathrm{H} 2020$ funding has gone to UK based automotive firms to develop new technologies. While the Chancellor has 'guaranteed' to plug science funding gaps arising from Brexit, it is not clear what this means in practice and whether British universities and firms (including in the auto industry) will be able to participate in, and benefit from, Horizon 2020 collaborative research networks in the future. Ideally what UK auto needs to see is continued British participation in Horizon 2020 and the key research networks and collaboration that this involves. That could in turn underpin private sector investment in new technologies in the sector. A final uncertainty here is over the role of the European Investment Bank which has made substantial support available to automotive firms in the UK to develop low carbon technologies such as more fuel efficient engines. With the UK leaving the EU, will such types of support still be forthcoming? That in turn brings us to the issue of industrial policy to which we turn below.

All of this suggests that a number of key priorities need to be spelled out a soon as possible in the UK's Brexit negotiating position so as to underpin investors' confidence in UK auto (and broader manufacturing). Firstly, access to the Single Market needs to be maintained as part of any transitional deal. As the EEF (2016) notes, the UK must be prepared to make a contribution to the EU in order to achieve this. Secondly, maintaining the skills base is critical - this includes enabling UK auto to hire skilled workers from Europe. Thirdly, and linked to the first point, regulatory cooperation with the EU needs to be ensured. Finally, measures need to be taken to underpin investment in the UK, boost productivity and to develop an effective industrial strategy (on the latter see Bailey et al, 2015).

\section{Brief implications for Industrial Policy}

Britain needs to more than just strike a new trade deal with the EU, whether a short term interim deal or a longer term trading relationship. For example, if Brexit brings with it an end to free movement and restrictions on recruiting skilled workers from the EU, then the UK will need to do much more to create and develop its own skills; this means developing better systems for education, skills training, and re-training as part 
of a wider industrial policy. Furthermore, given the recent depreciation in sterling, there is potentially a new opportunity here for reshoring the auto supply chain further. That is not going to happen automatically, though, given the barriers to reshoring that have been identified (e.g. access to finance, skills, availability of land, energy costs) (Bailey and De Propris, 2014). The new government under Theresa May has brought with it a welcome change of tone on industrial strategy, emphasizing (to a degree) its role in the economy; see for example the Industrial Strategy Green Paper (HMG, 2017). ${ }^{12}$ So what might a more effective industrial strategy for auto involve? Firstly, the government might consider looking again at the 'devolution offer' to regions and return to development bodies that can do 'smart specialization' through regional level industrial policies. Combined Authorities may be one way to do that (in cities at least), and are an area where the Business Secretary Greg Clark has much expertise. Strengthening the local growth hubs to fill the 'vacuum' left by the abolition of the Manufacturing Advisory Service (MAS) could be part of this 'Combined Authority Plus' model, as would further devolution of skills funding to the regional level so as to enable regions to address skills shortages locally (such as through controlling the Apprenticeship Levy locally).

Secondly, there is much more that the government could be doing in trying to 'rebalance' the economy and reduce Brexit-induced uncertainty, for example by stimulating investment in manufacturing such as through enhanced capital allowances, by resurrecting something like the Advanced Manufacturing Supply Chain Initiative (preferably on a wider scale), and by plugging funding gaps for small firms in the supply chain.

Returning to the 'Nissan deal', what exactly did the government offer Nissan and what does it tell us about the government's new industrial strategy and more broadly its negotiating stance on Brexit? On this we learned a little from the Business Secretary Greg Clark late last year (The Guardian, 30/11/16). Clark made it clear that a key UK objective in Brexit talks will be to avoid tariff barriers with the EU. He also made repeatedly reference to industry sectors and their different needs, implying that the UK would seek to negotiate sector-by-sector deals with the EU.

${ }^{12}$ For a response to and critique of the Green Paper, see Regional Studies Association (2017). 
That could see the UK trying to avoid non-tariff barriers in certain sectors like auto, effectively giving those sectors something like access to the Single Market. This suggests that the Business department at least sees access to the EU Single Market as a key negotiating objective for a transitional deal at least.

Clark's comments raised a number of points on which the government has been vague so far. Firstly, Clark seemed to imply that - as a minimum - the UK could remain in a customs union with the EU under a transitional deal. That would go a long way to reassuring the auto industry on tariffs. Secondly, if the UK really does want to trade without tariffs and non-tariff barriers, then the EU may well extract a 'price' in the form of a contribution to the EU budget, as made by Norway and Switzerland and noted above. Thirdly, some form of 'referee' may be needed to determine whether the UK is playing by the rules of whatever trade deal is done with the EU. That might be the WTO or a body linked to the EU. Fourth, despite Nissan wanting 'compensation' if tariffs are imposed, Clark has suggested that may not be possible under WTO rules. Finally, the government appears to have reiterated its support to the auto industry through the industrial strategy is now developing, on issues like skills, innovation and reshoring the supply chain. The latter is welcome, although further detail is required as part of the forthcoming White Paper.

\section{Conclusions}

The UK's automotive sector has been successful in recent years in growing output and - to a more limited degree - in sourcing more components locally. Brexit brings both opportunities and challenges to the industry and it is important that these are tackled effectively so that the industry can continue to thrive. The Brexit vote, for example, leaves considerable uncertainty over the nature of the UK's trading relationship with the EU. That uncertainty has the potential to impact on foreign investment in the UK auto sector, especially when auto firms are looking to replace models. While Nissan has made a decision to build the next generation Qashqai and XTrail models at Sunderland, this will be reviewed by Nissan once the terms of Brexit are clearer. Furthermore, other firms may hold off making decisions on assembly in the UK until they knows whether they will face tariffs when exporting to the EU. Plants and jobs could be at risk if such uncertainty isn't 'nailed down' quickly in the form of clear parameters for an interim or transitional trade deal - and preferably one 
that is as close as possible to existing Single Market arrangements. On this there is much more that the government could be doing in really trying to counter this uncertainty, for example by prioritising as part of the Brexit negotiations access to the Single Market under a transitional deal and ensuring that UK firms can hire skilled workers from Europe.

The UK also needs to do more than agree a new trading relationship with Europe It needs a new industrial strategy both to offset Brexit induced uncertainty and to 'rebalance' the economy, for example by stimulating investment in manufacturing such as through enhanced capital allowances, by resurrecting something like the Advanced Manufacturing Supply Chain Initiative (preferably on a wider scale), by devolving skills and training to the regional level, and by plugging funding gaps for small firms in the supply chain. There is the opportunity to 'reshore' more of the auto components industry if sterling settles down at the post Brexit referendum exchange rate. Reshoring is not going to happen automatically, though, given the barriers to reshoring noted above, and an effective industrial strategy is required to push this along. It should also be noted that the industry is undergoing profound changes, with shifts towards electrification, and connected and autonomous (driver-less) cars. A committed industrial strategy will be needed to underpin private sector investment in such technologies, a point which Jaguar Land Rover has been keen to stress regarding its aspiration to build electric vehicles in the UK (Bailey, 2016). On this we await more details from the government's new industrial strategy. A key point is that given both opportunities and risks arising from Brexit for UK auto, a more developed industrial strategy is needed to support UK automotive and manufacturing.

\section{References}

AutoExpress. Brexit spells uncertainty for UK car industry. 28/06/16.

Bailey, D (2016). JLR throws down the Gauntlet to Government, Birmingham Post, 29/11/2016.

Bailey, D (2017) Peugeot Citroen looks to take over GM Europe? Birmingham Post, 15/02/2017.

Bailey, D and De Propris, L (2014) Manufacturing Reshoring and its Limits: the UK Automotive Case, Cambridge Journal of Regions, Economy and Society, 7(3), 379398. 
Bailey, D and De Propris, L (2017) Brexit, UK Automotive and implications for industrial policy, in Bailey, D. and Budd, L, ed.s, (2017) The Political Economy of Brexit. London: Agenda Publishing.

Bailey, D and de Ruyter, A (2015) Plant Closures, Precariousness and Policy Responses: revisiting MG Rover ten years on, Policy Studies, 36(4), 363-383.

Bailey, D and Berkeley, N (2014) Regional Responses to Recession: A Case Study of the West Midlands, Regional Studies, 48(11), 1797-1812.

Bailey, D and Chapman, C (2017) Are we facing a car loan credit crunch? Here are the facts, The Conversation, Available at: http://theconversation.com/are-we-facinga-car-loan-credit-crunch-here-are-the-facts-83471 (last accessed 12/10/2017)

Bailey, D, Driffield, N and Karoglou, M (2017) Inward investment will fall in the UK, post Brexit, Columbia FDI Perspectives, Number 204. Available at:

https://academiccommons.columbia.edu/catalog/ac:31zcrjdfng (last accessed 12/10/2017)

Broughton, N, Keohane, N and Ketola, T (2016) Working Together? The impact of the EU referendum on UK employers. London: Social Market Foundation.

Coe N.M. and Yeung H.W. (2015) Global Production Networks, Oxford: Oxford University Press.

Dhingra, S, Ottaviano, G, Sampson, T and Van Reenen, J. (2016) The impact of Brexit on foreign investment in the UK. CEP Brexit Analysis Number 3. London: LSE Centre for Economic Performance.

Driffield, N and Karoglou, M (2016) Brexit and Foreign Investment in the UK, Social Science Research Network. Available at:

http://papers.ssrn.com/sol3/papers.cfm?abstract id=2775954 (last accessed 12/10/2017)

EEF (2016) Britain and the EU. Manufacturing an Orderly Exit. London: EEF.

Financial Times (2016) UK inflation approaches 2-year high, 16/08/2016.

Financial Times (2016) Nissan delays Sunderland investment decisions, 29/09/2016.

Financial Times (2017) Investment in UK car industry plummets amid Brexit uncertainty, 02/07/2017.

Gereffi G., Humphrey J. and Sturgeon (2016) The governance of global value chains, Review of International Political Economy, 12(1).

The Guardian (2016) Japanese Ambassador warns companies could leave UK over Brexit, 05/09/2016.

The Guardian (2016) Nissan in UK: Treasury refuses to tell OBR if cost attached to decision, 23/11/2016.

The Guardian (2016) Greg Clark's big reveal on 'demeanour' of Brexit negotiations strategy, 30/11/2016.

The Guardian (2017) UK exporters have 'hoarded' gains from fall in sterling, says ONS, 15/09/2017. 
Government of Japan (2016) Japan's Message to the United Kingdom and the European Union. Available at: http://www.mofa.go.jp/files/000185466.pdf (last accessed 12/10/2017)

Head, K. and T. Mayer (2015) 'Brands in Motion: How Frictions Shape Multinational Production', UBC Working Paper. Available at:

http://www.cepii.fr/PDF PUB/wp/2015/wp2015-26.pdf (last accessed 12/10/2017)

HMG (Her Majesty's Government) (2017) Building our Industrial Strategy. Green Paper. Available at: https://beisgovuk.citizenspace.com/strategy/industrialstrategy/supporting documents/buildingourindustrialstrategygreenpaper.pdf (last accessed 12/10/2017).

Holmes, P (2016) A special deal for the car industry: how could it work? http://www.sussex.ac.uk/eu/articles/brexit-special-deal (last accessed 12/10/2017)

House of Commons Library (2016) Briefing Paper Number 07213, Brexit: impact across policy areas. Available at:

http://researchbriefings.parliament.uk/ResearchBriefing/Summary/CBP7213\#fullreport (last accessed 12/10/2017)

Just Auto (2017) Toyota planning to build next Auris in UK, https://www.justauto.com/news/toyota-planning-to-build-next-auris-in-uk-report id179049.aspx (last accessed 12/10/2017).

KPMG (2014) The UK Automotive Industry and the EU. London: KPMG.

KPMG (2016) Brexit: How would business vote? London: KPMG.

LMC Automotive (2016) Client Alert: Implications of UK Vote to leave the European Union. London: LMC Automotive.

LMC Automotive (2016b) Client Alert: Brexit analysis update: UK vehicle industry risk; and what if things get worse? London: LMC Automotive.

Mathews, John A. "Dragon multinationals: New players in 21 st century globalization." Asia Pacific Journal of Management 23.1 (2006): 5-27.

PA Consulting (2016) Brexit: The Impact on Automotive Manufacturing in the UK. London: PA Consulting.

RSA (Regional Studies Association) (2017) Industrial Strategy Green Paper:

Regional Studies Association Response. Available:

http://www.regionalstudies.org/news/article/industrial-strategy-green-paper-regionalstudies-association-response (last accessed 12/10/2017).

Singh, A, G. Singh, D. Bailey and H. Lenihan. (2015). Takeovers and Takeovers Policy, in Bailey, D, Cowling, K, and Tomlinson, P (ed.s), New Perspectives on Industrial Policy for a Modern Britain. Oxford: Oxford University Press.

SMMT (Society of Motor Traders and Manufacturers) (2016) 2016 Sustainability Report. London: SMMT.

SMMT (Society of Motor Traders and Manufacturers) (2016b) Society of Motor Manufacturers and Traders 100th Annual Dinner Speech by Gareth Jones, SMMT President. London: SMMT.

SMMT (Society of Motor Traders and Manufacturers) (2017) June car manufacturing falls as industry calls on government to outline Brexit plans. London: SMMT. 
Unite the Union (2016) Brexit on our Terms. Unite Strategy to defend Manufacturing: Jobs, Investment and Employment Rights. London: Unite the Union. 